\title{
Peptide microarray mapping of B cell epitopes on bovine leukemia virus and peptide ELISA analysis of conservation of epitopes in BLV infected Japanese cattle
}

\author{
Lanlan Bai ${ }^{1,2}$, Shin-nosuke Takeshima1', Emiko Isogai ${ }^{2}$, Yoko Aida ${ }^{{ }^{*}}$ \\ From 17th International Conference on Human Retroviruses: HTLV and Related Viruses \\ Trois llets, Martinique. 18-21 June 2015
}

The bovine leukemia virus (BLV), a retrovirus structurally and functionally related to the human T-lymphotropic viruses HTLV-1 and HTLV-2, is the etiological agent of bovine leucosis. B cell immune mechanisms may play a major role in protection against BLV infection. A battery of 157 synthetic peptides, 15-mer length, 4 amino acids overlapped, was used to mapping B cell epitopes on BLV envelope glycoprotein gp5l and capsid protein by peptide microarrays. Two susceptible cattle with the homozygote BoLA-DRB3 *1601 allele and two non-susceptible cattle with DRB3 *1501/*2703 alleles and DRB3 *1501/*0503 alleles were infected with BLV, and serums were collected from those cattle each of having challenged BLV before and after. Only one epitope A out of 157 synthetic peptides responds with all of four BLV positive serums not their negative serums. To demonstrate whether epitope A is common B cell epitope or not by our established peptide ELISA system that uses maleimide activated mariculture keyhole limpet hemocyanin (mcKLH) carrier protein. To found, there are 7 kinds of BLV positive serum no response with epitope A among 232 kinds of positive serum. Furthermore, we searched other peptides respond with BLV positive serum that contain 7 kinds of serum no responded with epitope A and found epitope B among peptides of non-specifically responded on peptide microarray. Epitope B strongly responded with all of 232 kinds of serum as estimated by peptide ELISA system. Our results shows that epitope B has a tendency to react some BLV negative serums, thus we will perform further experiments to determine the common $\mathrm{B}$ cell epitope just responses

\footnotetext{
*Correspondence: aida@riken.jp
}

${ }^{1}$ Viral Infectious Diseases Unit, RIKEN, Wako, Saitama, Japan

Full list of author information is available at the end of the article with positive serum by peptides that are 3 alanine substitutions as shifting one amino acid on epitope sequence.

\section{Authors' details}

${ }^{1}$ Viral Infectious Diseases Unit, RIKEN, Wako, Saitama, Japan. ${ }^{2}$ Laboratory of Animal Microbiology, Department of Microbial Biotechnology, Graduate School of Agricultural Science, Tohoku University, Sendai, Miyagi, Japan.

Published: 28 August 2015

\section{doi:10.1186/1742-4690-12-S1-P97}

Cite this article as: Bai et al:: Peptide microarray mapping of B cell epitopes on bovine leukemia virus and peptide ELISA analysis of conservation of epitopes in BLV infected Japanese cattle. Retrovirology 2015 12(Suppl 1):P97.
Submit your next manuscript to BioMed Central and take full advantage of:

- Convenient online submission

- Thorough peer review

- No space constraints or color figure charges

- Immediate publication on acceptance

- Inclusion in PubMed, CAS, Scopus and Google Scholar

- Research which is freely available for redistribution

Submit your manuscript at www.biomedcentral.com/submit
() Biomed Central 